\title{
Hypovitaminosis D and Associated Risk Factors in Postmenopausal Women
}

\author{
Ana M. Masoni'1, Inés Menoyo', Roberto Bocanera ${ }^{2,3}$, Stella M. Pezzotto ${ }^{4}$, \\ Mario E. Morosano ${ }^{*}$ \\ ${ }^{1}$ Cátedra de Química Biológica, Facultad de Ciencias Médicas, Universidad Nacional de Rosario, Rosario, Argentina \\ ${ }^{2}$ Cátedra de Ginecología, Facultad de Ciencias Médicas, Universidad Nacional de Rosario, Rosario, Argentina \\ ${ }^{3}$ Centro de Estudios del Climaterio del Hospital Provincial del Centenario, Rosario, Argentina \\ ${ }^{4}$ Instituto de Inmunología, Facultad de Ciencias Médicas, Carrera del Investigador Científico, Consejo de \\ Investigaciones, Universidad Nacional de Rosario, Rosario, Argentina \\ Email: morosano@yahoo.com.ar
}

Received 29 March 2014; revised 1 May 2014; accepted 8 May 2014

Copyright $@ 2014$ by authors and Scientific Research Publishing Inc.

This work is licensed under the Creative Commons Attribution International License (CC BY). http://creativecommons.org/licenses/by/4.0/

(c) (i) Open Access

\begin{abstract}
Given the relevance of vitamin D in calcium metabolism homeostatic control, as well as its role as differentiation and cell proliferation modulator, it is important to study its circulating level in patients considered at risk, in order to develop prevention strategies. We studied 77 postmenopausal women with no history of osteoactive drug therapy, corticosteroid intake or diseases that could alter bone metabolism, attending the Menopause Center at the Hospital Provincial del Centenario, Rosario, Argentina. A medical history was taken, and a food consumption frequency questionnaire was applied in order to estimate daily calcium intake. To assess daily physical exercise, work and sports activities were investigated. Serum parathyroid hormone (PTH) and 25(OH)D were measured, and a hip DXA scan was performed in every patient. An inappropriate level of 25(OH)D was observed in $86.3 \%$ of patients. The $25(\mathrm{OH}) \mathrm{D}$ average value was found within the insufficiency range $(<30 \mathrm{ng} / \mathrm{ml})$ whereas PTH average concentration fell within the normal range, and bone mineral density average value was found within the osteopenic category. A statistically significant negative logarithmic association was observed between serum PTH level and vitamin $D$ status $(p=$ 0.01). Mean 25(OH)D concentration among patients who had reported fractures was significantly lower than the corresponding to women who had not suffered this type of event. Patients with vitamin D deficiency had significantly wider mean Cobb angle; higher sum of wedge angles of T4 T12 vertebral bodies mean values, and higher uncompromised vertebrae wedge angle values than non-deficient women. This study shows high hypovitaminosis D occurrence among these postmenopausal women.
\end{abstract}

${ }^{*}$ Corresponding author.

How to cite this paper: Masoni, A.M., Menoyo, I., Bocanera, R., Pezzotto, S.M. and Morosano, M.E. (2014) Hypovitaminosis $\mathrm{D}$ and Associated Risk Factors in Postmenopausal Women. Health, 6, 1180-1190. 


\section{Keywords}

\section{Vitamin D, Parathyroid Hormone, Post-Menopause, Vitamin D Deficiency}

\section{Introduction}

Vitamin D is an important regulator of bone and mineral metabolism. Its main source is synthesis in the deeper layers of the skin through the action of ultraviolet B rays (UVB) on its precursor 7-dehydrocholesterol [1]. Another source of vitamin D is the ingestion of certain foods, and the intake of supplements [2]. Its metabolic status is modified by environmental and individual factors such as latitude, season, skin pigmentation, body composition, aging, diet, clothing, and sunscreen use.

Serum 25(OH)D level has been considered as the most reliable indicator of vitamin D status [3]; it reflects the state of repletion or deficiency of vitamin $\mathrm{D}$ in the body [3]-[5].

Although there is no consensus among experts on what is the optimal concentration of 25(OH)D, a deficiency status has been defined for concentrations below $20 \mathrm{ng} / \mathrm{ml}$ [2] [6]. Values between 21 and $29 \mathrm{ng} / \mathrm{ml}$ have been considered as indicators of relative insufficiency, and values greater than $30 \mathrm{ng} / \mathrm{ml}$ have been considered appropriate [2] [6]-[8].

Vitamin D deficiency is a reemerging health problem worldwide, particularly considering its multiple health consequences (morbidity and mortality) [9] [10]. Regardless of the cutoff point chosen to assess the state of repletion or insufficiency of vitamin $\mathrm{D}$, a high prevalence of hypovitaminosis $\mathrm{D}$ has been observed in all age groups, especially in postmenopausal women from all regions of the planet [2] [11] [12]. Geographical variations have been observed, in relation to different conditions of latitude, heliophany, environmental characteristics, sociocultural behaviors and lifestyle [12]. An international study on 1285 subjects found that half of the postmenopausal women evaluated in three Latin American nations had deficient levels of vitamin D [12]. Prevalence of hypovitaminosis D has been studied in a sample of 339 healthy adults from different regions of Argentina. The mean serum 25(OH)D was lower in the South $(14.2 \pm 5.6 \mathrm{ng} / \mathrm{ml})$ compared to that in the Northern and Central regions (20.7 $\pm 7.4 \mathrm{ng} / \mathrm{ml}$, and $17.9 \pm 8.2 \mathrm{ng} / \mathrm{ml}$, respectively) [13].

A rise in parathyroid hormone (PTH) level may occur in response to low concentrations of vitamin $\mathrm{D}$, leading to an increase in bone remodeling and to a reduction in bone mass, both risk factors for osteoporotic fractures [2] [13] [14].

The main purpose of this study was to determine serum 25(OH)D concentration in a sample of postmenopausal women attending the Menopause Clinic at the Hospital Provincial del Centenario, and to evaluate the proportion of patients with 25(OH)D levels considered to be inadequate. Other goals were to explore the relationship between vitamin $\mathrm{D}$ metabolic status and other bone health risk factors in our patients, such as age, body mass index (BMI), sun exposure, parathyroid hyperfunction, femoral neck bone mineral density (BMD), history of fractures and thoracic spine morphometric variables (radiologic kyphosis—vertebral wedging).

\section{Patients and Methods}

From May to September, 77 healthy home-dwelling post-menopausal women were studied. This time period corresponds to Fall and Winter in the Southern hemisphere.

Women with history of osteoactive drug therapy, diseases that could alter bone metabolism, steroid medication or calcium and vitamin D supplements intake, were not included in the study. Patients underwent anamnesis, physical examination, and a food frequency questionnaire focused on dairy products consumption in order to estimate the daily intake of calcium. Daily physical activity was estimated from a seven day record of obligatory work (occupation), home duties, sports and recreational activities during leisure time plus sleeping hours as described elsewhere [15].

Weight was measured without shoes and in light indoor clothing using a clinical scale with a $0.1 \mathrm{~kg}$ precision. Height was measured by means of a stadiometer with a $0.1 \mathrm{~cm}$ precision. BMI was calculated by dividing weight in kilograms by the square of the height in meters.

Fasting blood and 24 hours urinary samples were obtained, and routine laboratory and specific bone metabol- 
ism tests were done. 25(OH)D and PTH serum concentrations were measured by chemiluminiscence; total serum and urinary calcium by colorimetric method, ionized calcium by selective ion electrode; serum phosphate and alkaline phosphatase by kinetic method.

In order to assess bone mineral density and to establish a diagnosis according to WHO criteria, a hip bone densitometry (DXA) was performed in each patient using a Lunar DPX equipment. Thoracic and lumbar spine X-ray films were performed to evaluate the presence of vertebral fractures defined according to Genant's method [16] and radiologic morphometry procedures were done in thoracic spine, as described elsewhere [17]. Morphometric variables calculated and considered in this study were Cobb angle, sum of wedge angles of T4 T12 vertebral bodies (SWA) and uncompromised vertebrae wedge angle average (MWA) as an indicator of structural vulnerability of non-fractured vertebrae [17].

Variables analysed were: 25(OH)D, PTH, total serum calcium and urinary calcium, ionized calcium, serum phosphate, alkaline phosphatase, BMD, BMI, age, age at menarche, menopause age and extension, parity, sun exposure, daily calcium intake, daily physical activity, history of fractures, immobilization for more than 30 days, Cobb angle, SWA and MWA.

Description of categorical data is presented as absolute frequencies and percentages. The differences between proportions have been evaluated by Chi-square tests and Lineal Trend Test when appropriate. Quantitative data are presented as mean \pm standard deviation (SD) and compared using Student's $t$ tests (for homogeneous or non homogeneous variances when appropriate). The analysis of small groups was performed using the Mann-Whitney $U$ test. To test the association of serum 25(OH)D with other variables, crude and age adjusted partial correlation coefficients were computed. To assess the association between serum 25(OH)D and PTH, a nonlinear logarithmic regression model was adjusted. With the aim of selecting the appropriate threshold of 25(OH)D in relation to the values of PTH, two groups of patients were considered, taking $69 \mathrm{pg} / \mathrm{ml}$ as the threshold. Values of 25(OH)D were used to compute sensitivity and specificity of different cutoffs points, a ROC curve was constructed, and the area under the curve was calculated. All analyses were conducted using STATA 8.0 and $\mathrm{p}<$ 0.05 was considered as statistically significant [18].

This investigation was approved by the School of Medicine Ethics Committee, National University of Rosario, Argentina. Written informed consent was obtained from each patient.

\section{Results}

Three patients (3.9\%) were excluded from the analysis because they decided not to complete the study procedures. The present results correspond to the remaining 74 patients.

Table 1 shows the mean values and SD for quantitative variables, and frequencies for the qualitative ones. Sixty one percent of the patients were younger than 65 years and of these women $75.6 \%$ were younger than 60 years. Appropriate BMI was observed in $23 \%$ of patients while overweight and obesity were found in $40.5 \%$ and $36.5 \%$, respectively. According to WHO criteria, $36.5 \%$ of patients had a normal T-score (>-1), $54.1 \%$ had low bone mass and $9.4 \%$ were osteoporotic.

When considering the values of 25(OH)D of all patients in the sample arranged in strata of $5 \mathrm{ng} / \mathrm{ml}$ (Figure 1), 64 patients had 25(OH)D levels below $30 \mathrm{ng} / \mathrm{ml}$. Of these women, $44.0 \%$ had values corresponding to the insufficiency category, whereas $42.5 \%$ had deficiency levels. Patients with inappropriate vitamin D concentrations were older than those showing appropriate levels, ages being $63.9 \pm 9.6$ and $57.7 \pm 6.5$ years, respectively $(\mathrm{p}=$ 0.052).

Significant correlations were found between 25(OH)D and age, menopause extension, BMD and BMI. After adjusting by age, only the association with BMI remained significant (Table 2).

When patients were stratified according to WHO criteria categories (T-scores $>-1.0 ;-1.0$ to $-1.49 ;-1.5$ to $-1.99 ;-2.0$ to -2.49 ; $\leq-2.5$ ), vitamin D deficiency was observed in $29.6 \%$; $26.7 \%$; $44.4 \% ; 60.0 \%$ and $100 \%$, respectively (lineal trend test: $\mathrm{p}=0.001$ ). Figure 2 shows this association.

Since sun exposure might influence serum 25(OH)D values, we compared these levels among women who reported voluntary sun exposure and those who have not exposed themselves to UV radiation deliberately. Although the average 25(OH)D serum concentration attained by women who used to expose themselves to sunlight $(26.2 \pm 9.9 \mathrm{ng} / \mathrm{ml})$ was significantly higher $(\mathrm{p}=0.004)$ than that achieved by those without that habit $(20.4$ $\pm 7.0 \mathrm{ng} / \mathrm{ml}$ ), it was found to be below $30 \mathrm{ng} / \mathrm{ml}$ in both groups.

When the sample was divided according to the patients' fracture history after the age of 40 years, it was found 
Table 1. Patients' general characteristics $(n=74)$.

\begin{tabular}{cc}
\hline Quantitative variables & Mean \pm SD \\
\hline Age (years) & $63.1 \pm 9.4$ \\
Menarche age (years) & $12.9 \pm 1.4$ \\
Menopause age (years) & $47.8 \pm 5.0$ \\
Menopause extention (years) & $15.3 \pm 10.4$ \\
25(OH)D (ng/ml) & $22.4 \pm 8.6$ \\
PTH (pg/ml) & $49.7 \pm 20.3$ \\
Serum calcium (mg/dl) & $9.3 \pm 0.5$ \\
Ionic calcium (mg/dl) & $4.1 \pm 0.6$ \\
Serum phophorus (mg/dl) & $4.5 \pm 0.6$ \\
Alcaline phophatase. (UI/l) & $187.6 \pm 54.3$ \\
Urinary calcium (g/24hs) & $162.1 \pm 92.4$ \\
Hip BMD (g/cm $\left.{ }^{2}\right)$ & $0.820 \pm 0.112$ \\
Cobb angle (degree) & $48.31 \pm 14.68$ \\
SWA (degree) & $31.28 \pm 12.66$ \\
MWA (degree) & $3.45 \pm 1.45$ \\
BMI (kg/m²) & $28.3 \pm 5.1$ \\
\hline Cualitative variables & Frequency (\%) \\
\hline Calcium intake $<1200$ mg/day & $42(56.8)$ \\
Physical activity $<2000$ Kcal/day & $31(45.9)$ \\
Sun exposure $>15$ min/day & $26(35.1)$ \\
In mobilization $>1$ month & $13(17)$ \\
Past history of fracture & $15(20.3)$ \\
\hline
\end{tabular}

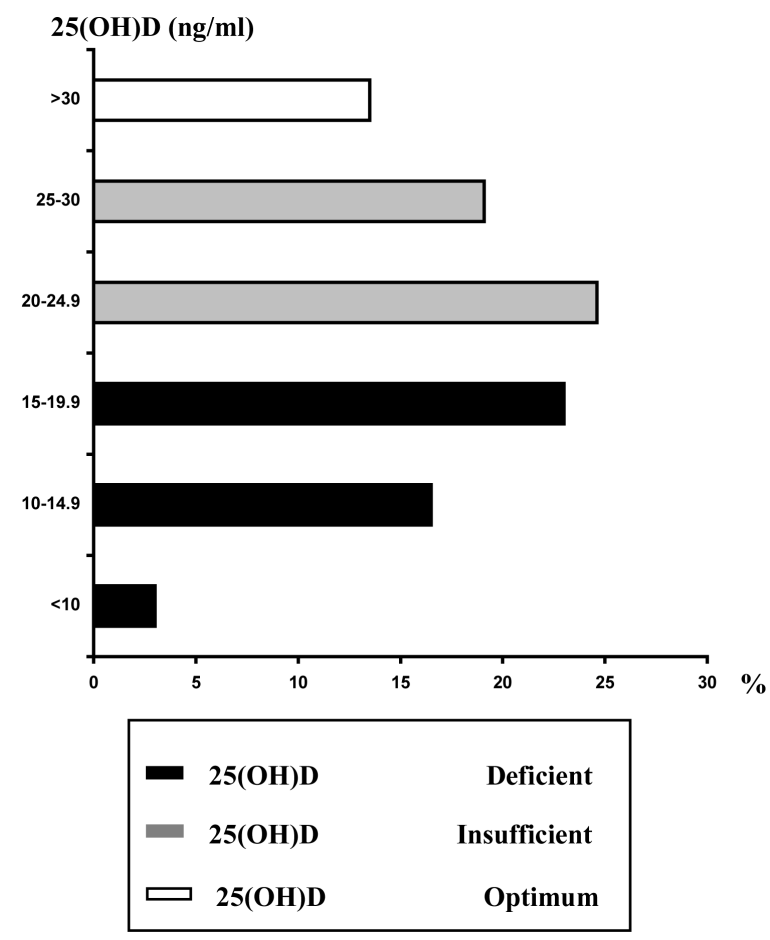

Figure 1. 25(OH)D serum level distribution and vitamin D status of the patients $(n=74)$. 
Table 2. Pearson and age-adjusted partial correlation coefficients between 25(OH)D and other variables.

\begin{tabular}{ccccc}
\hline \multirow{2}{*}{ Variables } & \multicolumn{2}{c}{ Crude correlation coefficients } & \multicolumn{2}{c}{ Age-adjusted partial correlation coefficients } \\
\cline { 2 - 5 } & $\mathbf{r}$ & $\mathbf{p}$ & $\mathbf{r}$ & $\mathbf{p}$ \\
\hline Age & $\mathbf{- 0 . 2 0 3}$ & $\mathbf{0 . 0 4 2}$ & - & - \\
Age at menarche & -0.068 & 0.283 & -0.094 & 0.216 \\
Age at menopause & 0.018 & 0.441 & 0.029 & 0.404 \\
Extension of menopause & $-\mathbf{0 . 1 9 5}$ & $\mathbf{0 . 0 4 9}$ & -0.037 & 0.380 \\
BMI & $-\mathbf{0 . 1 9 7}$ & $\mathbf{0 . 0 4 7}$ & $-\mathbf{0 . 2 5 1}$ & $\mathbf{0 . 0 3 3}$ \\
DMO & $\mathbf{0 . 1 9 3}$ & $\mathbf{0 . 0 5 1}$ & 0.109 & 0.180 \\
\hline
\end{tabular}

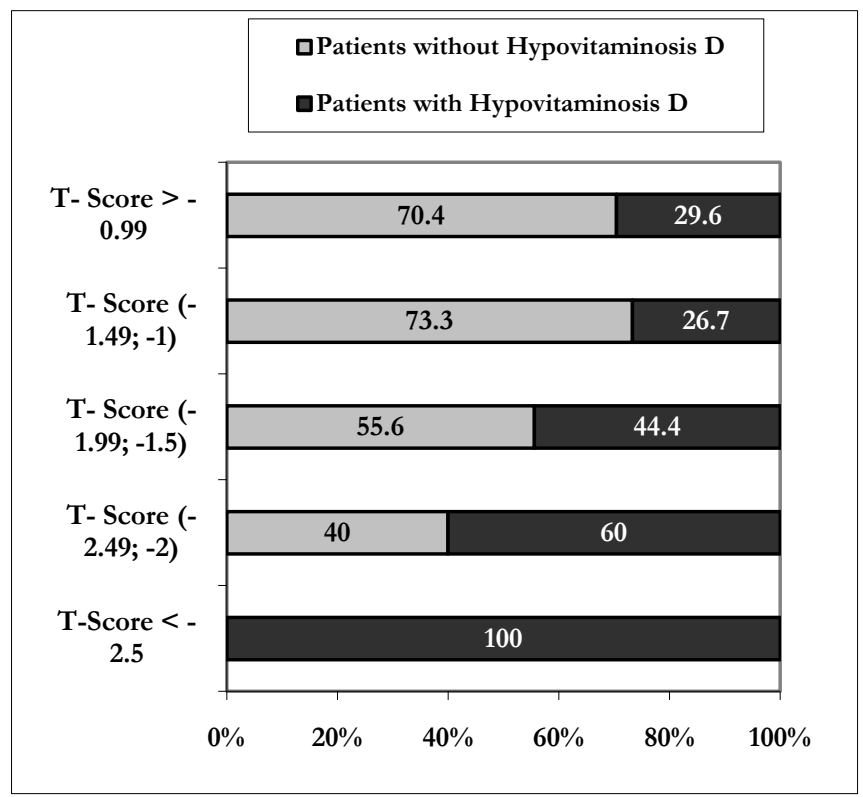

Figure 2. Association between vitamin D deficiency and T-score categories according to WHO criteria.

that the 25(OH)D mean concentration of patients who had reported fractures was significantly lower than that corresponding to the women who had not suffered this type of events $(16.3 \pm 6.0$ vs $23.2 \pm 8.6$; $p=0.030)$. The difference remained significant after adjusting for age and BMI $(\mathrm{p}=0.037)$.

A multivariate analysis was carried out considering 25(OH)D serum levels as dependent variable and age, BMI, sun exposure, menopause extension, BMD and history of fractures as independent variables. BMI showed a significant negative association $(p=0.017)$ and sun exposure a significant positive association $(p=0.006)$ with 25(OH)D serum concentration.

Parathyroid hyperfunction (PTH values $\geq 69 \mathrm{pg} / \mathrm{ml}$ ) was observed in $16.2 \%$ of the sample patients. Figure 3 shows the inverse relationship between serum PTH and vitamin D status. The logarithmic association found in this sample was statistically significant $(p=0.01)$. Table 3 shows the sensitivity and specificity for different 25(OH)D cutoff points. The area under the ROC curve was 0.809 ( $p=0.001)$. The cutoff point for 25(OH)D selected as optimum was $18.8 \mathrm{ng} / \mathrm{ml}$, with $74.2 \%$ sensitivity and $81.8 \%$ specificity. Patients with elevated PTH concentration and 25(OH)D level below the selected threshold did not differ in terms of their average age from women who had 25(OH)D serum level above the referred cutoff point (65.1 \pm 10.3 and $60.7 \pm 8.3$ years, respectively; $\mathrm{p}=0.10$ ). Figure 4 shows the association between parathyroid hyperfunction and history of fractures. The proportion of women with elevated PTH levels $(\geq 69 \mathrm{pg} / \mathrm{ml})$ was higher in those who had reported clinical axial or peripheral fractures (41.6\% versus 16.1\%; p < 0.04). Patients deficient in vitamin D ( $<20 \mathrm{ng} / \mathrm{ml}) \mathrm{had}$ significantly wider mean Cobb angle $(p=0.024)$ than non deficient women $(52.9 \pm 16.3$ and $44.5 \pm 12.4$, respectively); significantly higher SWA mean values (35.4 \pm 14.8 vs $28.2 \pm 10.0$; p =0.027) and significantly 


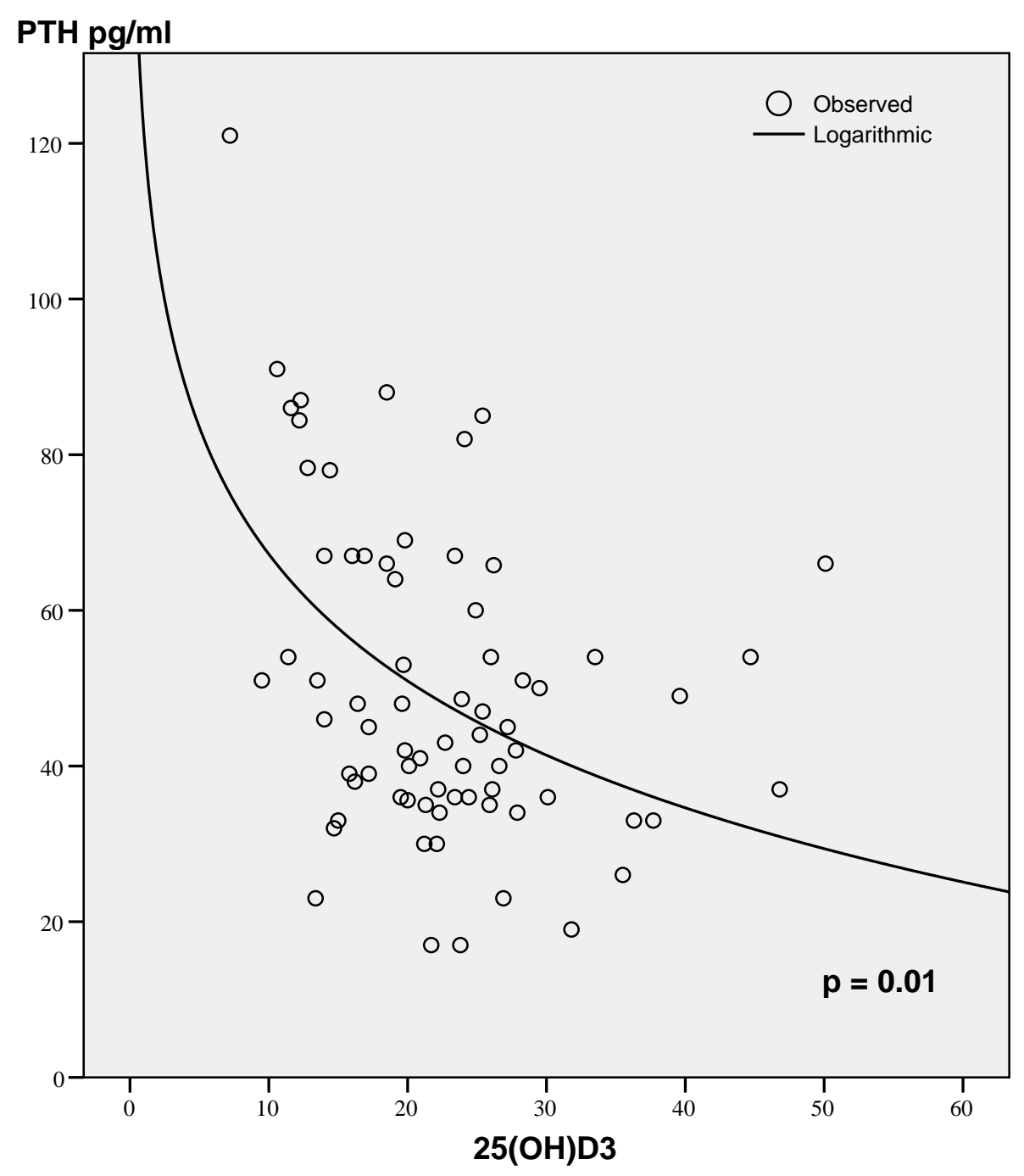

Figure 3. PTH level (pg/ml) as a function of 25(OH)D serum concentrations (ng/ml).

Table 3. Sensitivity and specificity (\%) for different cutoff values of 25(OH)D.

\begin{tabular}{ccc}
\hline $\mathbf{2 5}(\mathbf{O H}) \mathbf{D} \mathbf{~ n g} / \mathbf{m l}$ & Sensitivity & Specificity \\
\hline 8.4 & 100.0 & 9.1 \\
11.0 & 98.4 & 18.2 \\
14.9 & 88.7 & 63.6 \\
$\mathbf{1 8 . 8}$ & $\mathbf{7 4 . 2}$ & $\mathbf{8 1 . 8}$ \\
21.5 & 56.5 & 81.8 \\
25.1 & 37.1 & 90.9 \\
26.0 & 32.3 & 100.0 \\
\hline
\end{tabular}

higher MWA average values (3.9 \pm 1.7 vs $3.1 \pm 1.1$; $\mathrm{p}=0.035)$. To further explore the association between 25(OH)D and radiologic kyphosis expressed through these morphometric thoracic spine variables, eliminating the possible influence of vertebral fractures, 13 patients with prevalent vertebral fractures were excluded from this analysis. Table 4 shows the association between MWA and SWA and 25(OH)D in the remaining 61 patients without vertebral deformities and in the subgroup of inappropriate vitamin D status. In both groups, significant associations were found for MWA ( $p=0.012$ and 0.014 respectively) and SWA (0.013 and 0.015 respectively). 


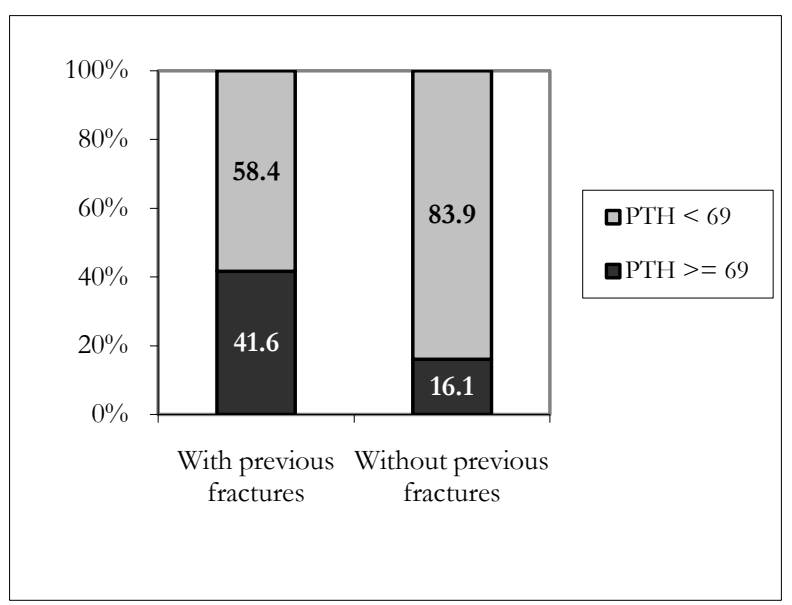

Figure 4. Patient distribution according to fracture history and PTH.

Table 4. Age-adjusted correlation coefficients between 25(OH)D and morphometric spine variables in patients without prevalent vertebral fractures.

\begin{tabular}{ccccc}
\hline & \multicolumn{2}{c}{ All patients } & \multicolumn{2}{c}{ Patients with $25(\mathbf{O H}) \mathbf{D}<\mathbf{3 0} \mathbf{~ n g} / \mathbf{m l}$} \\
\hline & $\mathrm{r}$ & $\mathrm{p}$ & $\mathrm{r}$ & $\mathrm{p}$ \\
\hline SWA (degree) & -0.37 & $\mathbf{0 . 0 1 3}$ & -0.40 & $\mathbf{0 . 0 1 5}$ \\
MWA (degree) & -0.37 & $\mathbf{0 . 0 1 2}$ & -0.40 & $\mathbf{0 . 0 1 4}$ \\
\hline
\end{tabular}

\section{Discussion}

This study shows the high prevalence of vitamin D deficiency (42.3\%) and insufficiency (86.5\%) found in these groups of outpatient postmenopausal healthy women currently attending the Menopause Clinic. Besides, a high proportion of subjects younger than 65 years, a predominant normal or low bone mass and a high frequency of overweight/obesity were observed. Therefore, these findings are particularly relevant since they were registered in a sample of mostly young women. The frequency of vitamin D insufficiency observed in our study is considerably higher than that reported by Fradinger et al. [19] who found that 46.4\% of patients from a sample of 198 postmenopausal women of similar average age to the patients in this study, living in the city of Buenos Aires (Latitude: $\left.34^{\circ} \mathrm{S}\right)$ had less than $30 \mathrm{ng} / \mathrm{ml}$. The average value of 25(OH)D observed in our sample $(22.4 \pm 8.6$ $\mathrm{ng} / \mathrm{ml}$ ) is similar to that found by Oliveri et al. [13] in another study carried out in 364 volunteers from different regions of Argentina. However, the mean age of our patients was lower than that cited by this group. A study performed in Santiago (Chile), a city located on the same latitude as Rosario $\left(33^{\circ} \mathrm{S}\right)$, in 60 postmenopausal women of similar age and BMI than the women from our study, reported an average 25(OH)D concentration of $19.5 \pm 9.9 \mathrm{ng} / \mathrm{ml}$ and a mean PTH level of $57.2 \pm 30.0 \mathrm{pg} / \mathrm{ml}[20]$.

A significant negative correlation was found between $25(\mathrm{OH}) \mathrm{D}$ and age in our patients, in agreement with the literature [20]-[22]. Significant associations were also observed with menopause extension, BMD and BMI, according to other authors' reports [23]-[26]. However, after age adjustment, in our sample no association was found among vitamin D levels and hip BMD, and only the association between 25(OH)D and BMI remained significant. Fradinger et al. [19] also found a modest correlation with hip BMD ( $\mathrm{r}=0.149, \mathrm{p}=0.036)$, but they failed to find a significant association between vitamin D status and lumbar spine BMD.

In agreement with other reports [21] [25]-[27], an inverse association was found between 25(OH)D and BMI, even after adjusting by several confounders. The finding of a mean BMI in the range of overweight has been systematically observed in our previous studies on postmenopausal women [15]-[17]. Adiposity could partially explain the high hypovitaminosis $\mathrm{D}$ prevalence rate in our patients.

Sunlight contribution to optimal vitamin D status is a controversial area [28]. Limited sunlight exposure (25\% of body surface/15 minutes a day) has been recommended to reach adequate 25(OH)D serum levels [29] [30]. In our study, as expected, patients exposed to sunlight showed higher $25(\mathrm{OH}) \mathrm{D}$ serum levels than those not ex- 
posed to solar radiation. However, the average 25(OH)D level achieved by women having reported habitual sunlight exposure, was found within the insufficiency range. Furthermore, $30.8 \%$ of these patients showed mean serum levels in the range of vitamin D deficiency $(<20 \mathrm{ng} / \mathrm{ml})$. These findings are in agreement with observations from other authors [31]-[33]. Several environmental and individual factors may influence the UVB effect on cutaneous vitamin D synthesis [34] [35] including ethnic variability [32] [33]. An interesting survey conducted in Lebanon, showed that residents from urban areas had lower vitamin D levels than inhabitants from rural regions [36]. Air pollution has been associated with vitamin D insufficiency [37] [38]. Rosario is a densely urbanized industrial area with a high pollution level. These environmental conditions deserve further investigation because they may be in part responsible for a lower proportion of UVB rays impinging on the body surface of the citizens. Therefore, it seems that in these postmenopausal women, voluntary sunlight exposure does not ensure an adequate vitamin D cutaneous synthesis. According to some authors, in the absence of appropriate sun exposure, children and adults of all ages would need a vitamin D supplementation between 800 and 1000 IU per day [39] [40].

In agreement with the literature, an inverse logarithmic relationship between 25(OH)D and serum PTH was confirmed [36] [41]. In a survey of more than 900 Australian women [42], PTH concentration was found to be associated with ionized calcium, age, weight and 25(OH)D concentration, with the latter variable being the determinant of greater significance in the multivariate analysis $(\mathrm{r}=-0.21)$. An interesting observation was that the weakest association found in the analysis was that between PTH level and age $(r=0.10)$. The cutoff point of the association between the concentrations of PTH and 25(OH)D in our study, defined by the ROC curve, was 18.8 $\mathrm{ng} / \mathrm{ml}$. Mean age of patients with elevated PTH concentration and 25(OH)D level below the selected threshold did not differ from women who had 25(OH)D serum level above the referred cutoff point, suggesting that the difference found in serum PTH levels in our sample is not due to the effect of age. In the Chilean study [20], the best discriminative $25(\mathrm{OH}) \mathrm{D}$ value to separate patients with and without parathyroid hyperfunction was 15 $\mathrm{ng} / \mathrm{ml}$. However, while $16.2 \%$ of patients in the present study had elevated PTH levels, this proportion was lower in the Chilean sample (7.5\%). A similar threshold value was reported by the Lebanese group [36]. Moreover, in the mentioned Australian study conducted by Need et al. [42], a significant PTH level increase occurred when serum 25(OH)D concentration fell to less than $20 \mathrm{ng} / \mathrm{ml}$.

The complex interaction among low vitamin D status, increased parathyroid response and bone fragility still remains unclear [43]. In our study, a positive relationship was observed between BMD (T-scores) and 25(OH)D concentrations in accordance with other studies [24]-[27] [43], although the association is lost after adjusting by age. In our sample, an association between fracture history and elevated PTH levels was observed. Besides, low vitamin D levels have been found associated with prevalent axial and peripheral fractures as shown in other reports [43]-[47]. In some [44]-[47] but not all of these studies [43] the significant role of increased parathyroid levels has been pointed out. In a recent prospective study, a cohort of healthy normocalcemic peri- and post-menopausal women was followed for 16 years. The risk of incident fractures was found to be significantly associated with increased PTH levels, and vitamin D status modified high PTH effects by increasing risk estimates with decreasing 25(OH)D concentrations [48]. The influence of low vitamin D status on vertebral fractures in postmenopausal women with elevated PTH levels has been reported recently [47].

As far as we know this is the first study indicating an association between low vitamin D status and morphometric thoracic spine variables. An increased Cobb angle in vitamin D deficient patients could be partly due to the observed prevalent vertebral fractures, as well as other issues that have not been examined (weakened muscles or degenerative disk disease). However, the finding of an inverse correlation between wedging of healthy non fractured vertebrae and 25(OH)D concentration is interesting. Low vitamin D status could take part in the kyphosis phenomenon contributing to the wedging deformity of still non-fractured thoracic vertebrae.

\section{Conclusion}

In conclusion, this study found a high prevalence of vitamin D deficiency and insufficiency in a sample of healthy postmenopausal women. The association between a poor vitamin D status, the increased BMI and the insufficient sun exposure; the inverse relationship between 25(OH)D and PTH levels; the observed relationship between history of fractures and parathyroid hyperfunction, and the association between low vitamin $\mathrm{D}$ and wedging of healthy vertebrae (SWA and MWA) seem to indicate that these women are a particularly vulnerable group from the bone health point of view. Since life expectancy of women in our region is 78.2 years [49], the 
findings that sunlight exposure does not assure appropriate vitamin D levels, and that prevalent hypovitaminosis and PTH hyperfunction may contribute to bone fragility, suggest that postmenopausal females attending our Menopause Clinic are at high risk of having prolonged suboptimal vitamin D status and suffer its consequences.

\section{Acknowledgements}

Acknowledging the limitations of this observational study-including the sample size and possible selection bias-it represents a contribution to the knowledge of this problem.

\section{References}

[1] Chen, T.C., Chimeh, F., Lu, Z., Mathieu, J., Person, K.S., Zhang, A., Kohn, N., Matinello, S., Berkowitz, R. and Holick, M.F. (2007) Factors That Influence the Cutaneous Synthesis and Dietary Sources of Vitamin D. Archives of Biochemistry and Biophysics, 460, 213-217. http://dx.doi.org/10.1016/j.abb.2006.12.017

[2] Holick, M.F. (2007) Vitamin D Deficiency. New England Journal of Medicine, 357, 266-281. http://dx.doi.org/10.1056/NEJMra070553

[3] Haroon, M. and Regan, M.J. (2010) Vitamin D Deficiency: The Time to Ignore It Has Passed. International Journal of the Rheumatic Diseases, 13, 318-323. http://dx.doi.org/10.1056/NEJMra070553

[4] Audran, M. and Briot, K. (2010) Critical Reappraisal of Vitamin D Deficiency. Joint Bone Spine, 77, 115-119. http://dx.doi.org/10.1016/j.jbspin.2009.12.003

[5] Binkley, N., Krueger, D. and Lensmeyer, G. (2009) 25-Hidroxy Vitamin D Measurement, 2009: A Review for Clinicians. Journal of Clinical Densitometry, 12, 417-427. http://dx.doi.org/10.1016/j.jocd.2009.06.001

[6] Dawson-Hughes, B., Heaney, R.P., Holick, M.F., Lips, P., Meunier, P.J. and Vieth, R. (2005) Estimates of Optimal Vitamin D Status. Osteoporosis International, 16, 713-716. http://dx.doi.org/10.1007/s00198-005-1867-7

[7] Holick, M.F. (2009) Vitamin D Status: Measurement, Interpretation, and Clinical Application. Annals of Epidemiology, 19, 73-78. http://dx.doi.org/10.1016/j.annepidem.2007.12.001

[8] Holick, M.F. (2006) High Prevalence of Vitamin D Inadequacy and Implications for Health. Mayo Clinic Proceedings, 81, 353-373. http://dx.doi.org/10.4065/81.3.353

[9] Pérez-López, F.R., Chedraui, P. and Fernández Alonso, A.M. (2011) Vitamin D and Aging: Beyond Calcium and Bone Metabolism. Maturitas, 69, 27-36. http://dx.doi.org/10.1016/j.maturitas.2011.02.014

[10] Mithal, A., Wahl, D.A., Bonjour, J.P., Burckhardt, P., Dawson-Hughes, B., Eisman, J.A., El-Hajj Fuleihan, G., Josse, R.G., Lips, P., Morales-Torres, J., On Behalf of the IOF Committee of Scientific Advisors (CSA) Nutrition Working Group (2009) Global Vitamin D Status and Determinants of Hipovitaminosis D. Osteoporosis International, 20, 18071820. http://dx.doi.org/10.1007/s00198-009-0954-6

[11] Gaugris, S., Heaney, R.P., Boonen, S., Kurth, H., Bentkover, J.D. and Sen, S.S. (2005) Vitamin D Inadequacy among Postmenopausal Women: A Systematic Review. QJM, 98, 667-676. http://dx.doi.org/10.1093/qjmed/hci096

[12] Rizzoli, R., Eisman, J.A., Norquist, J., Ljunggren, O., Krishnarajah, G., Lim, S.K. and Chandler, J. (2007) Risk Factors for Vitamin D Inadequacy among Women with Osteoporosis: An International Epidemiological Study. International Journal of Clinical Practice, 60, 1013-1019. http://dx.doi.org/10.1111/j.1742-1241.2006.01066.x

[13] López Giovanelli, J., Ponce, G., Nieva, A., Chaperón, A., Ladizesky, M., Somoza, J., Casco, C., Zeni1, S., Parisi, M.S. and Mautalen, C.A. (2004) High Prevalence of Vitamin D Insufficiency in Healthy Elderly People Living at Home in Argentina. European Journal of Clinical Nutrition, 58, 337-342. http://dx.doi.org/10.1038/sj.ejcn.1601786

[14] Kuchuk, N.O., Pluijm, S.M.F., van Schoor, N.M., Looman, C.W., Smit, J.H. and Lips, P. (2009) Relationships of Serum 25-Hidroxyvitamin D to Bone Mineral Density and Serum Parathyroid Hormone and Markers of Bone Turnover in Older Persons. The Journal of Clinical Endocrinology and Metabolism, 94, 1244-1250. http://dx.doi.org/10.1210/jc.2008-1832

[15] Masoni, A., Morosano, M., Pezzotto, S.M., Tomat, F., Bentancur, F., Bocanera, R., Tozzini, R. and Puche, R.C. (2005) Construction of Two Instruments for the Presumptive Detection of Post-Menopausal Women with Low Spinal Bone Mass by Means of Clinical Risk Factors. Maturitas, 51, 314:324.

[16] Genant, H.K., Wu, C.Y., Van Kuijk, C. and Nevitt, M.C. (1993) Vertebral Fracture Assessment Using a Semiquantitative Technique. Journal of Bone and Mineral Research, 8, 1137-1148. http://dx.doi.org/10.1002/jbmr.5650080915

[17] Morosano, M., Menoyo, I., Caferra, D., Sánchez, A., Tomat, F., Bocanera, R., Pezzotto, S.M. and Masoni, A.M. (2011) Vulnerability of Healthy Vertebrae in Patients with and without Previous Vertebral Fracture. Bone, 48, 820-827. http://dx.doi.org/10.1016/j.bone.2010.12.014

[18] Stata Corporation. STATA 8.0. Statistics/Data Analysis. 
[19] Fradinger, E.E. and Zanchetta, J.R. (2001) Vitamin D and Bone Mineral Density in Ambulatory Women Living in Buenos Aires, Argentina. Osteoporosis International, 12, 24-27. http://dx.doi.org/10.1007/s001980170153

[20] González, G., Alvarado, J.N., Rojas, A., Navarrete, C., Velásquez, C.G. and Arteaga, E. (2007) High Prevalence of Vitamin D Deficiency in Chilean Healthy Postmenopausal Women with Normal Sun Exposure: Additional Evidence for a Worldwide Concern. Menopause, 14, 455-461. http://dx.doi.org/10.1097/GME.0b013e31802c54c0

[21] Freedman, D.M., Cahoon, E.K., Rajaraman, P., Major, J.M., Doody, M.M., Alexander, B.H., Hoffbeck, R.W., Kimlin, M.G., Graubard, B.I. and Linet, M.S. (2013) Sunlight and Other Determinants of Circulating 25-Hydroxyvitamin D Levels in Black and White Participants in a Nationwide US Study. American Journal of Epidemiology, 77, 180-192. http://dx.doi.org/10.1093/aje/kws223

[22] Millen, A.E., Wactawski-Wende, J., Pettinger, M., Melamed, M.L., Tylavsky, F.A., Liu, S., Robbins, J., LaCroix, A.Z., LeBoff, M.S. and Jackson, R.D. (2010) Predictors of Serum 25-Hydroxyvitamin D Concentrations among Postmenopausal Women: The Women's Health Initiative Calcium plus Vitamin D Clinical Trial. The American Journal of Clinical Nutrition, 91, 1324-1335. http://dx.doi.org/10.3945/ajcn.2009.28908

[23] Bandeira, F., Griz, L., Freese, E., Castro Lima, D., Thé, A.C., Trovào Diniz, E., Marques, T.F. and Lucena, C.S. (2010) Vitamin D Deficiency and Its Relationship with Bone Mineral Density among Postmenopausal Women Living in the Tropics. Arquivos Brasileiros de Endocrinologia \& Metabologia, 54, 227-232. http://dx.doi.org/10.1590/S0004-27302010000200020

[24] Bischoff-Ferrari, H.A., Kiel, D.P., Dawson Hughes, B., Orav, J.E., Li, R., Spiegelman, D., Dietrich, T. and Willett, W.C. (2009) Dietary Calcium and Serum 25-Hydroxyvitamin D Satus in Relation to BMD among US Adults. Journal of Bone and Mineral Research, 24, 935-942. http://dx.doi.org/10.1359/jbmr.081242

[25] Chacko, S.A., Song, Y., Manson, J.E., Van Horn, L., Eaton, C. and Martin, L.W. (2011) Serum 25-Hydroxyvitamin D Concentrations in Relation to Cardiometabolic Risk Factors and Metabolic Syndrome in Postmenopausal Women. The American Journal of Clinical Nutrition, 94, 209-217. http://dx.doi.org/10.3945/ajcn.110.010272

[26] McCullough, M.L., Weinstein, S.J., Freedman, D.M., Helzlsouer, K., Flanders, W.D. and Koenig, K. (2010) Correlates of Circulating 25-Hydroxyvitamin D. American Journal of Epidemiology, 172, 21-35. http://dx.doi.org/10.1093/aje/kwq113

[27] Young, K.A., Engelman, C.D., Langefeld, C.D., Hairston, K.G., Haffner, S.M., Bryer-Ash, M. and Norris, J.M. (2009) Association of Plasma Vitamin D Levels with Adiposity in Hispanic and African Americans. The Journal of Clinical Endocrinology and Metabolism, 94, 3306-3313. http://dx.doi.org/10.1210/jc.2009-0079

[28] Macdonald, H.M. (2013) Contributions of Sunlight and Diet to Vitamin D Status. Calcified Tissue International, 92, 163-176. http://dx.doi.org/10.1007/s00223-012-9634-1

[29] Hanley, D.A., Cranney, A., Jones, G., Whiting, S.G., Leslie, W.D. and Cole, D.E.C. (2010) Guidelines Committee of the Scientific Advisory Council of Osteoporosis Canada. Vitamin D in Adult Health and Disease: A Review and Guideline Statement from Osteoporosis Canada. CMAJ, 182, E611-E618. http://dx.doi.org/10.1503/cmaj.091062

[30] Pérez-López, F.R., Brincat, M., Tamer Erel, C., Tremollieres, F., Gambacciani, M., Lambrinoudaki, I., Moen, M.H., Schenck-Gustafsson, K., Vujovic, S., Rozenberg, S. and Rees, M. (2012) EMAS Position Statement: Vitamin D and Postmenopausal Health. Maturitas, 71, 83-88. http://dx.doi.org/10.1016/j.maturitas.2011.11.002

[31] Binkley, N., Novotny, R., Krueger, D., Kawahara, T., Daida, Y.G., Lensmeyer, G., Hollis, B.W. and Drezner, M.K. (2007) Low Vitamin D Status Despite Abundant Sun Exposure. The Journal of Clinical Endocrinology and Metabolism, 92, 2130-2135. http://dx.doi.org/10.1210/jc.2006-2250

[32] Jacobs, E.T., Alberts, D.S., Foote, J.A., Green, S.B., Hollis, B.W., Yu, Z. and Martinez, M.E. (2008) Vitamin D Insufficiency in Southern Arizona. The American Journal of Clinical Nutrition, 87, 608-613.

[33] Oren, Y., Shapira, Y., Agmon-Levin, N., Kivity, S., Zafrir, Y., Altman, A., Lerner, A. and Shoenfeld, Y. (2010) Vitamin D Insufficiency in a Sunny Environment: A Demographic and Seasonal Analysis. IMAJ, 12, 751-756.

[34] Holick, M., Chen, T.C., Lu, Z. and Sauter, E. (2007) Vitamin D and Skin Physiology: A D-Lightful Story. Journal of Bone and Mineral Research, 22, V28-V32. http://dx.doi.org/10.1359/jbmr.07s211

[35] Tsiaras, W.G. and Weinstock, M.A. (2011) Factors Influencing Vitamin D Status. Acta Dermato-Venereologica, 91, 115-124.

[36] Gannagé-Yared, M.H., Chemali, R., Yaacoub, N. and Halaby, G. (2000) Hypovitaminosis D in Sunny Country: Relation to Lifestyle and Bone Markers. Journal of Bone and Mineral Research, 15, 1856-1862. http://dx.doi.org/10.1359/jbmr.2000.15.9.1856

[37] Manicourt, D.H. and Devogelaer, J.P. (2008) Urban Tropospheric Ozone Increases the Prevalence of Vitamin D Deficiency among Belgian Postmenopausal Women with Outdoor Activities during Summer. The Journal of Clinical Endocrinology and Metabolism, 93, 3893-899. http://dx.doi.org/10.1210/jc.2007-2663

[38] Hosseinpanah, F., Pour, S.H., Heibatollahi, M., Moghbel, N., Asefzade, S. and Azizi, F. (2010) The Effects of Air Pol- 
lution on Vitamin D Status in Healthy Women: A Cross Sectional Study. BMC Public Health, 10, 519-524. http://dx.doi.org/10.1186/1471-2458-10-519

[39] Holick, M.F. and Chen, T.C. (2008) Vitamin D Deficiency: A Worldwide Problem with Health Consequences. American Journal of Clinical Nutrition, 87, 1080S-1086S.

[40] Heaney, R.P., Davies, K.M., Chen, T.C., Holick, M.F. and Barger-Lux, M.J. (2003) Human Serum 25-Hydroxycholecalciferol Response to Extended Oral Dosing with Cholecalciferol. American Journal of Clinical Nutrition, 77, 204210.

[41] Valcour, A., Blocki, F., Hawkins, D.M. and Rao, S.D. (2012) Effects of Age and Serum 25-OH-Vitamin D on Serum Parathyroid Hormone Levels. The Journal of Clinical Endocrinology and Metabolism, 97, 3989-3995. http://dx.doi.org/10.1210/jc.2012-2276

[42] Need, A.G., O’Loughlin, P.D., Morris, H.A., Horowitz, M. and Nordin, B.E.C. (2004) The Effects of Age and Other Variables on Serum Parathyroid Hormone in Postmenopausal Women Attending an Osteoporosis Center. The Journal of Clinical Endocrinology and Metabolism, 89, 1646-1949. http://dx.doi.org/10.1210/jc.2003-031539

[43] Yamauchi, M., Kaji, H., Nawata, K., Takaoka, S., Yamaguchi, T. and Sugimoto, T. (2011) Role of Parathyroid Hormone in Bone Fragility of Postmenopausal Women with Vitamin D Insufficiency. Calcified Tissue International, 88, 362-369. http://dx.doi.org/10.1007/s00223-011-9464-6

[44] Jang, W.Y., Chung, M.S., Baek, G.H., Song. C-H., Cho, H.E. and Gong, H.S. (2011) Vitamin D Levels in Post-Menopausal Korean Women with a Distal Radius Fracture. Injury, 43, 237-241. http://dx.doi.org/10.1016/j.injury.2011.10.020

[45] Dhanwal, D.K., Sahoo, S., Gautam, V.K. and Saha, R. (2013) Hip Fracture Patients in India Have Vitamin D Deficiency and Secondary Hyperparathyroidism. Osteoporosis International, 24, 553-557. http://dx.doi.org/10.1007/s00198-012-1993-y

[46] Seitz, S., Koehne, T., Ries, C., De Novo Oliveira, A., Barvencik, F., Busse, B., Eulenburg, C., Schinke, T., Püschel, K., Rueger, J.M., Amling, M. and Pogoda, P. (2013) Impaired Bone Mineralization Accompanied by Low Vitamin D and Secondary Hyperparathyroidism in Patients with Femoral Neck Fracture. Osteoporosis International, 24, 641-649. http://dx.doi.org/10.1007/s00198-012-2011-0

[47] Hernández, J.L., Olmos, J.M., Pariente, E., Nan, D., Martínez, J., Llorca, J., Valero, C., Obregón, E. and GonzálezMacías, J. (2013) Influence of Vitamin D Status on Vertebral Fractures, Bone Mineral Density and Bone Turnover Markers in Normocalcemic Postmenopausal Women with High Parathyroid Hormone Levels. The Journal of Clinical Endocrinology and Metabolism, 98, 1711-1717. http://dx.doi.org/10.1210/jc.2012-3931

[48] Rejnmark, L., Vestergaard, P., Brot, C. and Mosekilde, L. (2011) Increased Fracture Risk in Normocalcemic Postmenopausal Women with High Parathyroid Hormone Levels: A 16-Year Follow-Up Study. Calcified Tissue International, 88, 238-245. http://dx.doi.org/10.1007/s00223-010-9454-0

[49] Ministerio de Salud (2011) Indicadores básicos 2011. Presidencia de la Nación, Argentina. http://www.msal.gov.ar/images/stories/pdf/indicadores-nacion-2011.pdf 